\title{
Psycholinguistic Correlates of Progress in Literature at Russian Vocational Training School: A Snap Shot from Selected Paper
}

\author{
Putri Adrian Sapitri \\ Vocational High School 5, Pekanbaru, Indonesia \\ putriadriansapitri14@gmail.com
}

\begin{abstract}
ARTICLE HISTORY
Received : 9 May 2019

Revised : 17 May 2019

Accepted : 27 May 2019
\end{abstract}

\section{KEYWORDS}

Psycholinguistics

Literature

Vocational

Correlation

Article Review

\begin{abstract}
This article aims to present a little snapshot from the author's perspective as a review article paper. The research article written by Nuriakhmetov entitled "Psycholinguistic Correlates of progress in Literature of Students of Russian Vocational Training School" was selected to be the object of this study's exploration. David Publishing published Nuriakhmetov's article in 2012 in their Journal of Psychological Research Volume 2 Issue 12. This present article used descriptive qualitative analysis to bring about comprehension to the readers' minds. This article has seen literacy as a person's ability to handle their potential and develop their skills in processing and understanding information while carrying out reading and writing activities. This study explores how the relationship between the nature of students with each other and the ability of students with the transfer of professional disciplines including Literature, English, Russian, and Bashkir according to Nuriakhmetov's article. The article seems to have a clear flow on how to explain these two types of education and make this journal easy to understand. Therefore, the present study sees Nuriakhmetov's article to be replicable for similar studies in the future.
\end{abstract}

\section{Introduction}

The journal, entitled "Psycholinguistic Correlation of Progress in Student Literature in the Vocational Training School in Russia" was written by Aidar Nuriakhmetov from Sterlitamak Branch, Bashkir State University, Sterlitamak, Russia. Aidar Nuriakhmetov published this journal at David Publishing in December 2012, Vol.2, No. 12, 706-710. This research journal consists of 5 pages.

According to the metadata of the selected article, the researcher and author is Aidar Nuriakhmetov. This author's article discussed the development of individual talks (reading and writing) with the character of students' psychology (p. 1) so that this journal is interesting to review because other Psychology journals until 2019 still focus on professional skills (Flores, Martinez, McGillen, \& Milord, 2019). This journal wants to present the correlation of psycholinguistic progress in literacy (Language Learning) (p. 1).

Literacy is inseparable from education. Literacy is a means for students to know, understand, and apply the knowledge they get at school (Nelson, Courier, \& Joseph, 2019). Literacy is a person's ability to use potential and skills in processing and understanding information while carrying out reading and writing activities (Snowling, Duff, Nash, \& Hulme, 2016). By reading, students can expand knowledge, add information, add ideas, and increase student interest in a field so that the influence of text is obvious on improving students' thinking (Zalf, 2011). Mustafa (2014) argues that literacy, in its most fundamental form, contains the notion of the ability to read, write, and think critically. To have literacy skill is to not take for granted of what someone receives from their environments, both real and virtual (Alvermann \& Sanders, 2019).

From the various definitions above, the authors conclude that literacy can be interpreted as the ability to read, write, view, and design things by being accompanied by critical thinking skills that cause someone to communicate effectively and efficiently so that it creates meaning for the world. That is, with someone literate is someone who reads and writes with the ability to process information obtained from reading and writing activities.

Writing skills and other languages need to be possessed by students. Writing skills are one of the productive and expressive language skills that are used to communicate indirectly and not face to face with other parties (Allgood, Seedal, \& Williams, 2019; Tarigan, 2008). Literacy is also related to the lives of students, both at home and the surrounding environment to cultivate noble character.

The language processing in use which is known as discourse analysis (DA) is the way of accepting interactions in social areas including written and spoken discourse (Gee Michaels, \& Mary-Catherine, 2017; Sari, Putri, Herdi, \& Hamuddin, 2018). More clearly, Literacy is also a language ability possessed by someone in communication such as reading, speaking, listening and writing (Teale \& Sulzby, 1986). Through psychology, one will learn how attitudes and behaviours in acquiring and learning languages, while through linguistics, people can learn about the concepts and 
structure of the word itself (Natsir, 2017). This study aimed to find out how the relationship between the nature of students with each other and the ability of students to transfer professional disciplines including Literature, English, Russian, and Bashkir (p. 1).

This research the author carried out for two years involving 100 male students (p. 1). The author examines using six sets of methods to measure the elements the author wants. The reason the researchers involved 100 male students was none other than that the development of speech and personal psychology gave a direct effect on the ability to read and write students as a basis for taking over professional discipline (Kaiser Ward-Lonergan Pieretti, Cragg, Swanson, Lambert, Ostrowski-Gallagher, \& Phillips, 2016).

The four subjects which include Literature, English, Russian and Bashkir are student activities that are carried out every day and every time in the lives of students as social beings (Wijaya, Mulyati, Damaianti, \& Sumiyadi, 2018). According to the world economic forum, 2016 students need 16 skills to be able to survive in the XXI century. Namely basic literacy (how students apply literacy skills to everyday life, competence (how students respond to complex challenges), and character (how students respond to changes in the environment).

This character value can be realized through efforts to improve the skills of multiliterate of students with a focus on literacy, cultural literacy and citizenship, scientific literacy, numeracy literacy, digital literacy, and financial literacy. Currently, school activities are not yet optimal in developing the literacy abilities of students and teachers. It may be due to the lack of understanding of the importance of literacy skills in life.

Low literacy is a fundamental problem that has a vast impact on the progress of the nation. Low literacy contributes to the low productivity of the country (McGivney \& Winthrop, 2016; Zwart \& Baker, 2018). It leads to low growth and ultimately affects the low level of welfare which is characterized by low per capita income (Lin, Lee, Azari, \& Migliaccio, 2018). To read for one's self imporvement, Literacy learning is essential for students because the ability to understand is the basis for mastering several knowledge or fields of study that children must learn in school. High reading interest with the support of proper facilities and infrastructure will increase high reading interest and will become a habit or become a reading culture in the community.

Thus, reading is not innate but is a result of habits in life. That is, reading needs to be implanted from childhood and carried out with continuous habitation. Lack of reading will cause one's creativity not to develop. As educators know, the creative mindset will be realized if the person develops an open mindset and is able to respond to the environment quickly, and this can be trained with reading activities.
Creative ideas that arise indeed can make someone become more productive. A creative mind can provide benefits not only for the person who has it but also for those around the person involved. In fact, if one lacks a healthy interest to read, or at least to find out more about the environment around them and the world beyond them, that person may have a difficult time to improve their creativity. Ignorance because it is reluctant to add knowledge and upgrade yourself to the latest information will cause indifference. Eventually, this will make the concerned close himself and busy with his world and neglecting the surrounding environment.

\section{Method}

This study used a qualitative research method that is used by selecting the article that is relevant to link psycholinguistics with educational skills, particularly literature. This study used qualitative as the research design because this study intends to focus purely on the forms of word data and give a minimum focus on the selected article's numerical data. The reason for this distinction is because it is much easier to review the quality of the way the selected article was written rather than the exact methodological steps that the article's owner or owners must have went through to produce their results.

The process of selecting and reviewing the selected article is shown in Figure 1. 


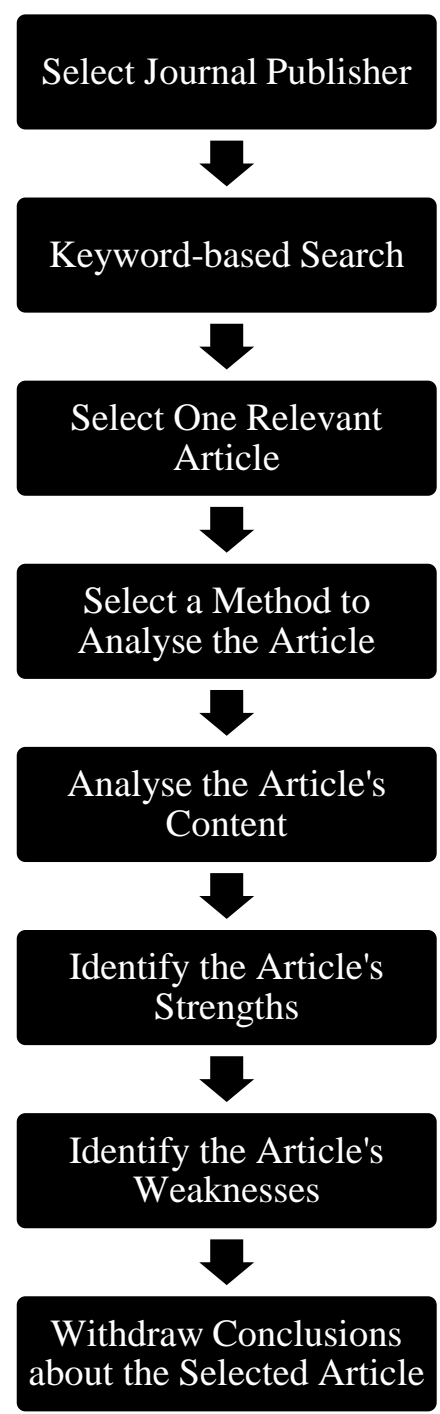

Figure 1. Methodological Process

This study first selected a highly reputable academic publisher, namely Springer, as the electronic database where this study searched the article. Using the keywords 'psycholinguistics' and 'literature', this study randomly selected Nuriakhmetov's 2012 article as the subject for review.

The next step is analyzing using descriptive qualitative. This method is chosen because it deals with purely qualitative data, which will be in the form of words, so it is suited for an article review in which the primary data is the words contained in the selected article (Cho, 2017; Johnson, 2018). Descriptive qualitative will be used so the researcher can focus on identifying the strengths and weakness of the selected article. Further, this method enables the researcher to withdraw a conclusion by seeing the pattern and information in the articles. To find out what kind of the effect if students have high Literacy (Reading and Writing) values based on a review analyzed in this study found in a journal entitled Psycholinguistic Correlates of Progress in Literature of Students of the Russian Vocational Training School studied by Aidar Nuriakhmetov.

Therefore, this review-based study tries to describe the journal made by Nuriakhmetov (2012) based on the findings of the high literacy effect in the Study of Russian Vocational Training school as well as looking at the strengths and weakness aspects of the journal. This research hopes to be able to provide a simple description while recommending the findings or steps in the journal whether it is feasible to be replicated or not in the same study.

\section{Results}

In writing a journal there must be advantages and disadvantages and in a journal entitled "Correlation of Psycholinguistic Progress in the Literature of Student Vocational Training Schools" published by Aidar Nuriakhmetov in December 2012, Vol.2, No. 12, 706 -710. In the title section, the author has entered the location of the sample taken so that it is more focused and specific.

Based on the writing system in this journal, there are several advantages possessed by the journal. On page 1, there is an Abstract, Introduction and Methods. In abstract sections, this journal summarizes journal objectives, methods, results, and conclusions, and this will function to digest the contents of the entire journal briefly. The keywords in the journal match the keyword limits suggested by Cambridge Core, which is 3-5. In the punctuation section, there are no punctuation errors or writing errors in the journal.

So, it can be said that the journal's author should have good accuracy in journal writing. The language used by the author is also easy to read, making it easier for readers to understand what a journal means. This journal is significant research because in discussions about everyday things or events because in social life one must use language to communicate with each other and language is the most complete and effective communication to convey ideas, messages, meanings, feelings and opinion to others (Walijaya, 1996).

Furthermore, in method section has been presented in detail and clearly about the six sets of methods that I use, what is interesting from this study is the various types of tests that the author wants to prove that what kind of character students have-high literary value. The literary value here focuses on developing students' speaking abilities which have a direct effect not only on human values but on all general subjects. For the sample, the author explains the criteria and how many samples were taken.

Regarding the data sample and data analysis that the selected article used, this study easily identified that the sample in Nuriakhmetov's study was unanimously male students majoring in "car mechanics" and "agricultural 
industry foremen" aged 15-19 (p. 1). This study uses value analysis correlation and the results of several psychological tests conducted by the author using qualitative and quantitative methods.

In addition, the results of the study are presented in table form. The discussion section is an essential part of all journal content. The purpose of the discussion is to answer the research problem or show how the research objectives are achieved. In this discussion, the researcher discussion broadly interprets hypotheses and research data so that each relationship and correlation between variables are visible.

On pages two to page four, there is a result of research conducted by the author. In the first test with 16 questions, the author gets results if someone who has a high literary value has characteristics that are friendly and helpful to friends. On the second test, students are required to answer 88 questions whose results are someone who has a high literature value, hyperthymic, stickling, and emotive. On the third test, there were 105 questions that students had to answer, and the results were students who had high literature values, so the students were not easily upset. In the fourth text, 40 questions result if students who have a high literature value, then the student has organizational and communicative abilities. On the fifth test students must react with 20 words spoken by the examiner by writing them down, students who have a high literature value then the students write longer. And the last test is a test that aims to examine the level of the intellectual development of students in which results from students who have a high literary value can fill in the text of the passages tested by researchers. From the six tests carried out, the authors explain very detailed what is produced from each text so that readers can describe what the criteria of the writer in measuring student literacy. On page five, there are conclusions and conclusions.

Based on the description, it can be concluded that the systematics of journal writing is neatly arranged, coherent and complete. In the punctuation section, there are no punctuation errors or writing errors in the journal. So I can just say the author this journal has good accuracy in paying attention to writing the contents of the journal. The language used by the author is generally easy to understand. Still, several languages are difficult to translate such as Hyperthymic and stickling (p. 3) other languages can be recognised so that it is easier for the reader to know how the research is carried out and what results are obtained. In the title, some words confuse the reader about "Literature" because usually when hearing about literature one would imagine creative activities or a series of works of art (Wellek, \& Warren, 1990). However, Literature referred to by the author is literacy which is a person's ability to use potential and skills in processing and understanding information when reading and writing activities. More clearly, Literacy is also a language ability possessed by someone in communication such as reading, speaking, listening and writing (Teale \& Sulzby, 1986).
In the abstract, the author also does not include what recommendations are given for further research. The researcher examined six methods that were very well described. One method has been the focus in particular, known as Character Accuracy, as it is named by LeonhardSmishek (Nuriakhmetov, 2012). Still, this variable was not explained by the author Characteristics of the application of a typological approach to his study. Although the methods and results are well explained, the conclusions drop dramatically (p. 5), and not even every discussion, and conclusions must contain the essence or idea of an idea writing or event written with sufficient and adequate information so that the reader knows the proof of the hypothesis (Kuntoko, 2014). The findings and weaknesses in this study were found; the study concluded that students who have high literacy values would have the characteristics desired by the author.

\section{Implications}

As a study conducted by researcher Aidar Nuriakhmetov in December 2012, Vol.2, No. 12, 706-710, this journal has implications in the level of education. The results of research with six methods show significant results. The functions of literacy are not only beneficial for literacy but also in shaping the character of wise, creative, critical, and caring people who can sympathize, empathize, engage in self, fellow human beings, and the environment his life.

However, for psychological testing conducted by researchers, it might be less convincing to be a guideline that someone who has a high literacy value will have the character described by the researcher. Because, before a psychological test can be used, it must go through a validity test that ensures that the psychological test is able to accurately measure specific aspects of the individual (Suryabrata, 1993). For testing the psychological test validity, the author does not mention the question so that it can make the reader doubtful in the results found by the author. In the process of learning activities carried out to improve literacy skills have not run optimally.

In addition to students, teachers also need to improve their abilities and awareness of literacy. So in overcoming these problems, it takes effort and effort from the teacher and the students themselves by making improvements, and the teacher needs to incorporate literacy strategies in all general subjects not only on humanitarian values (p. 1). The development of literacy skills will help improve students 'learning abilities which will ultimately determine the professional success of students' growth and socialization. The aspects examined by the author are carried out with a combination of quantitative and qualitative approaches further to deepen the relationship between psycholinguistic correlation and literacy. Further research is needed to get more tangible results. 


\section{Conclusion}

The results of this study found that students who have high literacy values (reading and writing) have friendly characteristics, carry out activities with enthusiasm, can arrange, will focus on doing something, can write longer and can fill in riding texts. It has a direct impact on human values but all general subjects. Speech development and characteristic psychology have an immediate effect on the ability to read and write students as a basis for taking over professional discipline. The effect is very influential on student activity. It appears every day and every time in the lives of students as social beings (Wijaya, Mulyati, Damaianti, \& Sumiyadi, 2018). If a student who does not have high literacy values for eating can be sure that the student is not an expert in reading and writing. Therefore, every human being must continue to process literacy activities. The journal they created seems to have a clear flow of ways to explain these two types of education and make this journal easy to understand. Therefore it can be easily replicated for similar research purposes.

High reading interest with the support of excellent facilities and infrastructure will increase high reading interest and will become a habit or become a reading culture in the community. Thus reading is not innate but is a result of habits in life. That is, reading needs to be implanted from childhood and carried out with continuous habitation.

\section{Acknowledgement}

The author of this article gives their gratitude to the Applied Linguistics Center for their help in the discussion sessions during the time of writing this article. Everything contained in this article, however, does not reflect their opinions and is the opinions, values, and judgments of the author.

\section{References}

Allgood, S. M., Seedall, R. B., \& Williams, R. B. (2019). Expressive Writing and Marital Satisfaction: A Writing Sample Analysis. Family Relations.

Alvermann, D. E., \& Sanders, R. K. (2019). Adolescent literacy in a digital world. The international encyclopedia of media literacy, 1-6.

Cho, J. (2017). Evaluating qualitative research. Oxford University Press.

Flores, L. Y., Martinez, L. D., McGillen, G. G., \& Milord, J. (2019). Something Old and Something New: Future Directions in Vocational Research With People of Color in the United States. Journal of Career Assessment, 27(2), 187-208.

Gee, J. P., Michaels, S., \& Mary-Catherine, O. C. (2017). Discourse analysis. The handbook of qualitative research in education.
Johnson, T. N. (2018). A simple descriptive qualitative study: Teacher mentoring and novice teacher resilience (Doctoral dissertation, Grand Canyon University).

Kaiser, H., Ward-Lonergan, J., Pieretti, R., Cragg, S., Swanson, T., Lambert, K. R., Ostrowski-Gallagher, A., \& Phillips, D. (2016). Roles and Responsibilities of Speech-Language Pathologists with Respect to Literacy in Children and Adolescents in California. Speech-Language-Hearing Association.

Kuntoko, A. D. (2014). Menulis kesimpulan dan saran pada penelitian. (Retrieved on: March $20^{\text {th }} 2019$ ) http://oc.its.ac.id/ambilfile.php?idp=1309,

Lin, K. Y., Lee, W., Azari, R., \& Migliaccio, G. C. (2018). Training of low-literacy and low-english-proficiency Hispanic workers on construction fall fatality. Journal of Management in Engineering, 34(2), 05017009.

McGivney, E., \& Winthrop, R. (2016). Education's impact on economic growth and productivity.

Natsir, N. (2017). Hubungan Psikolinguistik dalam Pemerolehan dan Pembelajaran Bahasa. RETORIKA: Jurnal Bahasa, Sastra, dan Pengajarannya, 10(1).

Nelson, K., Courier, M., \& Joseph, G. W. (2019). An investigation of digital literacy needs of students. Journal of Information Systems Education, 22(2), 2.

Nuriakhmetov, A. (2012). Psycholinguistic Correlates of Progress in Literature of Students of Russian Vocational Training School. Online Submission, 2(12), 706-710.

Sari, R., Putri, S. E., Herdi, H., \& Hamuddin, B. (2018). Bridging critical discourse analysis in media discourse studies. Indonesian EFL Journal, 4(2), 8089.

Snowling, M. J., Duff, F. J., Nash, H. M., \& Hulme, C. (2016). Language profiles and literacy outcomes of children with resolving, emerging, or persisting language impairments. Journal of Child Psychology and Psychiatry, 57(12), 1360-1369.

Suryabrata, S. (1993). Psikologi Pendidikan dan Evaluasi Belajar.

Tarigan, H. G. (2008). Menulis sebagai keterampilan berbahasa. Bandung: Angkasa.

Teale, W. H., \& Sulzby, E. (1986). Emergent literacy as a perspective for examining how young children become writers and readers. Emergent literacy: Writing and reading, 7-25.

Walijaya. (1996). Bahasa Indonesia dalam Perbincangan. Jakarta: IKIP Muhammadiyah Jakarta Press. 
Wijaya, R., Mulyati, Y., Damaianti, V. S., \& Sumiyadi, S. (2018, December). Developing Reading Skills and Beginning Writing through Literary Literacy. In International Conference on Language, Literature, and Education (ICLLE 2018). Atlantis Press.

Zwart, S., \& Baker, M. (2018). Improving productivity and job quality of low-skilled workers in the United Kingdom. 